\title{
Erratum to: Single-cell whole genome sequencing reveals no evidence for common aneuploidy in normal and Alzheimer's disease neurons
}

Hilda van den Bos ${ }^{1}$, Diana C. J. Spierings ${ }^{1}$, Aaron Taudt ${ }^{1,2}$, Bjorn Bakker ${ }^{1}$, David Porubský ${ }^{1}$, Ester Falconer $^{3}$, Carolina Novoa ${ }^{3}$, Nancy Halsema ${ }^{1}$, Hinke G. Kazemier ${ }^{1}$, Karina Hoekstra-Wakker', Victor Guryev', Wilfred F. A. den Dunnen ${ }^{4}$, Floris Foijer', Maria Colomé-Tatché ${ }^{1,2}$, Hendrikus W. G. M. Boddeke ${ }^{5}$ and Peter M. Landsdorp ${ }^{1,3,6^{*}}$

\section{Erratum}

After the publication of this work [1] it was noticed that there were errors in two author names.

The author names should appear as Aaron Taudt and Maria Colomé-Tatché.

This has been updated in the original article.

\begin{abstract}
Author details
'European Research Institute for the Biology of Ageing (ERIBA), University of Groningen, University Medical Center Groningen, 9713, AV, Groningen, The Netherlands. ${ }^{2}$ Institute for Computational Biology, Helmholtz Zentrum München, Ingolstädter Landstr. 1, 85764 Neuherberg, Germany. ${ }^{3}$ Terry Fox Laboratory, BC Cancer Agency, Vancouver, BC V5Z 1L3, Canada. ${ }^{4}$ Section of Pathology, Department of Pathology and Medical Biology, University of Groningen, University Medical Center Groningen, 9713, AV, Groningen, The Netherlands. ${ }^{5}$ Section Medical Physiology, Department of Neuroscience, University of Groningen, University Medical Center Groningen, 9713, AV, Groningen, The Netherlands. ${ }^{6}$ Division of Hematology, Department of Medicine, University of British Columbia, Vancouver, BC V6T 1Z4, Canada.
\end{abstract}

Received: 22 June 2016 Accepted: 22 June 2016

Published online: 30 June 2016

\section{Reference}

1. van den Bos H, Spierings CJ, Taudt A, Bakker B, Porubský D, Falconer E, et al. Single-cell whole genome sequencing reveals no evidence for common aneuploidy in normal and Alzheimer's disease neurons. Genome Biol. 2016;17:116.

\footnotetext{
* Correspondence: p.m.landsdorp@umcg.nl

${ }^{1}$ European Research Institute for the Biology of Ageing (ERIBA), University of Groningen, University Medical Center Groningen, 9713, AV, Groningen, The Netherlands

${ }^{3}$ Terry Fox Laboratory, BC Cancer Agency, Vancouver, BC V5Z 1L3, Canada Full list of author information is available at the end of the article
}

\footnotetext{
Submit your next manuscript to BioMed Central and we will help you at every step:

- We accept pre-submission inquiries

- Our selector tool helps you to find the most relevant journal

- We provide round the clock customer support

- Convenient online submission

- Thorough peer review

- Inclusion in PubMed and all major indexing services

- Maximum visibility for your research
}

Submit your manuscript at www.biomedcentral.com/submit 